\title{
Trichodiniasis in Nile tilapia hatcheries: Diagnosis, parasite:host-stage relationship and treatment
}

\author{
G.M.R. Valladão, L.O. Alves, F. Pilarski * \\ Aquaculture Center (CAUNESP), Universidade Estadual Paulista (UNESP), Jaboticabal, São Paulo, Brazi
}

\section{A R T I C L E I N F O}

\section{Article history:}

Received 28 August 2015

Received in revised form 26 September 2015

Accepted 28 September 2015

Available online 22 October 2015

\section{Keywords:}

Trichodina

Tripartiella

Paratrichodina

Pathology

Formaldehyde

\begin{abstract}
A B S T R A C T
Trichodiniasis is one of the major diseases found in fish worldwide. However, little is known regarding the effects of parasitism according to the life stage of the host in captivity. Moreover, there is a lack of knowledge regarding the treatment of parasitic infections of fish. In this study, taxonomic identification (morphological and morphometric description) of trichodinids in Brazil and a comparison of parasitism in larvae and juveniles were performed using scanning electron microscopy, and the effectiveness of treatment with formaldehyde and sodium chloride was assessed. Six species of trichodinids (Trichodina centrostrigata, Trichodina migala, Trichodina heterodentata, Trichodina compacta, Tripartiella orthodens and Paratrichodina africana) were identified as parasites of Nile tilapia. The larvae showed a greater number of alterations, which were also more severe compared with juveniles. The outer surfaces of the infected larvae (integument, eye and fins) were highly affected, whereas the juveniles were rarely affected. A conventional treatment protocol using formaldehyde $\left(1 \mathrm{~mL} \mathrm{~L}^{-1}\right)$ and sodium chloride (1\%) for 15 min was highly effective. However, a protocol using half the amount of the disinfectant showed similar results $(p>0.05)$, whereas another protocol (using one quarter the amount of formaldehyde) was less effective than both of these protocols $(p<0.05)$. The results achieved here provide the first report of T. migala and T. orthodens in South America. The findings regarding the parasite:host relationship suggests that fish larviculture is highly affected and hence should be the main area of focus for the prevention and control of this type of parasitism. Preventive measures and indoor production strategies during the first days of fish hatching are highly recommended. Furthermore, this study shows that half the amount of formaldehyde than conventionally used can achieve the same efficacy in the treatment of trichodiniasis.

Statement of relevance: Trichodiniasis is one of the major diseases that occurs in aquaculture. It affects the production of several fish species throughout the world and has deleterious effects on cichlid (e.g., tilapia) production in particular. There are some available studies on the parasite:host relationship in nature. However, little is known about the effects of this disease in the farming environment. Herein, the diagnosis of exotic specimens, the relationship of parasitism with fish life stages in captivity (three fish farms) and treatment protocols are discussed.
\end{abstract} (c) 2015 Elsevier B.V. All rights reserved.

\section{Introduction}

Trichodiniasis is a parasitic disease caused by protozoans of the family Urceolariidae that affects various aquatic organisms. Members of this family are commonly referred to as trichodinids and are divided into various genera, the most common of which are Trichodina Ehrenberg, 1838, Paratrichodina Lom, 1963, Tripartiella Lom, 1959, Trichodinella (Raabe, 1950) Sramek-Husek, 1953 and Dipartiella (Raabe, 1959) Stein, 1961. Over 270 species of trichodinids have been described

\footnotetext{
* Corresponding author at: Rod. Paulo Donato Castellane, s/n CEP: 14.884-900, Jaboticabal, São Paulo, Brazil.
}

E-mail address: fabianap@caunesp.unesp.br (F. Pilarski).
(Mitra et al., 2013), but few studies have addressed their relationship with the host in captivity.

Infestations caused by trichodinids are particularly significant in aquaculture because they are responsible for causing decreased growth (Ekanem and Oblekezie, 1996), a decreased immune response in vaccinated fish (Martins et al., 2011), chronic mortality during cage production (Valladão et al., 2013) and changes in vision and swimming in larvae, culminating in acute mortality (Valladão et al., 2014). In studies addressing the pathology associated with this parasitic infestation, the main changes that have been described have been related to gill tissue, such as hyperplasia, hypertrophy, oedema, inflammatory infiltration and necrosis (Abdel-Baki et al., 2011; Yemmen et al., 2011a,b; Valladão et al., 2013, 2014).

There is a lack of knowledge regarding parasitic disease treatments for fish worldwide. Fish farmers have used disinfectants such as 
formaldehyde for the control of parasitic diseases (Valladão et al., 2015a). Although the use of these substances is permitted in some regions, such as North America (Shao, 2001), in other regions (where it is not legal), these substances are even used in the absence of labelling. Thus, the effectiveness of some treatments is not fully known. A commonly used treatment protocol and other protocols involving smaller quantities of disinfectant are discussed in this report.

The Nile tilapia Oreochromis niloticus Linnaeus, 1758 is one of the major cultivated fish species and is distributed worldwide. This species and cichlids in general are among the main hosts for trichodinids. The trichodinid species that are most frequently reported as parasites of Nile tilapia are Trichodina centrostrigeata Basson, Van As and Paperna, 1983, Trichodina compacta Van As and Basson, 1989, Trichodina magna Van As and Basson, 1989 and Paratrichodina africana Kazubski and ElTantawy, 1986; these have also been identified in South America (Jerônimo et al., 2011; Bittencourt et al., 2014; Zago et al., 2014). In this study, new reports of trichodinid specimens identified in Nile tilapia cultivated in South America are described.

The present study provides new reports of trichodinids in South America, compares trichodiniasis in larvae and juveniles, and discusses the effectiveness of treatment in cultured Nile tilapia.

\section{Materials and methods}

\subsection{Fish farms and fish collection}

This study was performed at the Laboratory of Aquatic Organism Pathology (LAPOA) of the Aquaculture Center of UNESP, in partnership with three commercial hatcheries with a history of parasitism by trichodinids. The experimental procedures were approved by the Ethics and Animal Welfare Committee (CEBEA) of the School of Agricultural Sciences and Veterinary Medicine of São Paulo State University (UNESP), Jaboticabal, SP, Brazil, under protocol number 04128/14.

Samples were collected at two fish farms in the state of São Paulo State and one in the state of Minas Gerais. The fish farms are identified as follows: hatchery A (located in São Paulo - 21 ${ }^{\circ} 51^{\prime} 14^{\prime \prime}$ S; $47^{\circ} 28^{\prime} 45^{\prime \prime}$

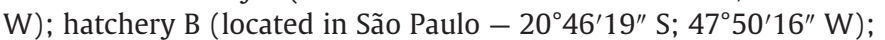
and hatchery C (located in Minas Gerais - 19 $11^{\prime} 54^{\prime \prime}$ S; $47^{\circ} 43^{\prime} 38^{\prime \prime} \mathrm{W}$ ).

Hatcheries A and B were selected to collect Nile tilapia larvae, whereas hatchery $C$ was selected to collect juveniles (approx. $2 \mathrm{~cm}$ ). Larvae were considered to be animals with the presence of a yolk sac and a phenotype distinct from that of the adult stage. Juveniles were considered to be animals that presented a similar phenotype to that of adult fish but that had not reached sexual maturity.

\subsection{Parasitic diagnosis and taxonomic evaluation}

In hatcheries A and B, ten Nile tilapia larvae were collected from earthen ponds, euthanised via medullar sectioning, compressed between a slide and cover slip and evaluated under an optical light microscope $(400 \times)$. After drying (at room temperature), the intensity of parasitism was assessed by counting the total number of parasites present in each larva deposited on the glass slides.

In hatchery $\mathrm{C}$, ten juveniles were collected from an earthen pond and euthanised via medullar sectioning. Their whole body surfaces were subsequently scraped, and the collected mucus was deposited on a glass slide. The gills (all arches) were collected separately from the body mucus and deposited between a slide and cover slip. This material was also analysed fresh under an optical light microscope $(400 \times)$.

Slides with parasites were air-dried and subsequently impregnated with silver nitrate (2\%) for the evaluation of all taxonomic characters (Klein, 1958), except for nuclear characters, which were measured on slides stained with Giemsa (Lom, 1958). Morphometric characters were measured as described by Arthur and Lom (1984). All measurements were performed on photomicrographs obtained with a Nikon E200® light microscope equipped with a Motic 5.0 image capture system. Descriptions were performed following recommendations of Lom (1958) and Van As and Basson (1989). Measurements were performed using Image Pro Plus ${ }^{\circledR}$ software. The obtained measurement data were described as the mean \pm standard deviation (minimummaximum; number of repetitions).

Schematic drawings of the trichodinid denticles were produced as proposed by Van As and Basson (1989) by using CorelDRAW®X6 software.

\subsection{Host-parasite interactions}

The objective was to compare the effect of the trichodiniasis on the first two life stages of the fish: the larvae and juveniles. Hatchery A (larvae) and hatchery C (juvenile) were selected to compare the effect of parasitism on the different life stages of Nile tilapia, which was studied through scanning electron microscopy (SEM).

For SEM analysis, 10 animals from each fish farm were collected. The animals were fixed in $2.5 \%$ glutaraldehyde and post-fixed in $1 \%$ osmium tetroxide (both with cacodylate buffer). Subsequently, the biological material was gradually dehydrated in alcohol and critical point dried. The dried material was placed on aluminium "stubs" and then coated with gold and analysed using a Zeiss Leo 1430 microscope. The whole body surfaces of the larvae and juveniles were analysed, focusing on the fins, scales, skin, eyes and gills.

\subsection{Treatment}

The effectiveness of a therapeutic protocol and the potential to decrease the use of formaldehyde were evaluated. A conventionally used treatment (TR 1 ) is formaldehyde $\left(1 \mathrm{~mL} \mathrm{~L}^{-1}\right)$ with sodium chloride (1\%). This treatment was compared with a protocol (TR 2) using formaldehyde $\left(0.5 \mathrm{~mL} \mathrm{~L}^{-1}\right)+$ sodium chloride $(1 \%)$ and another protocol (TR 3) using formaldehyde $\left(0.25 \mathrm{~mL} \mathrm{~L}^{-1}\right)+$ sodium chloride (1\%). Bath treatment was performed once for a period of $15 \mathrm{~min}$.

Parasitised larvae were collected from earthen ponds at fish farms A. The initial parasitism was assessed through the parasitological analysis of ten larvae. The remainder of the larvae were distributed in 9 plastic tanks (2 L). Each tank received 20 larvae. After 15 min, six larvae (18 per treatment) from each tank were collected for parasitological analysis. The parasites were counted, and the effectiveness of treatment (\%) was calculated using the formula $T E=100-\left(\frac{A \times 100}{B}\right)$, where TE is the treatment efficacy (\%); A is the average number of parasites after treatment; and $\mathrm{B}$ is the average number of parasites before treatment.

\subsection{Statistical analysis}

The treatment data were analysed using R software. The data were tested for homogeneity and homoscedasticity (Levene and CramerVon Mises tests, respectively) and subjected to one-way ANOVA and Tukey's test, in which probabilities less than or equal to 0.05 were considered statistically significant.

\section{Results}

\subsection{Parasite identification: fish farm A}

Moderate parasitism (197.67 \pm 202.24 trichodinids/fish) was observed in the larvae collected at hatchery A. The identified species were T. centrostrigeata and Trichodina migala Van As and Basson, 1989, both of which were observed in the skin of the larvae. T. migala was more abundant.

T. centrostrigeata (Fig. 1A) was of medium size and displayed structures characteristic of this species, referred to as centre ridges. 

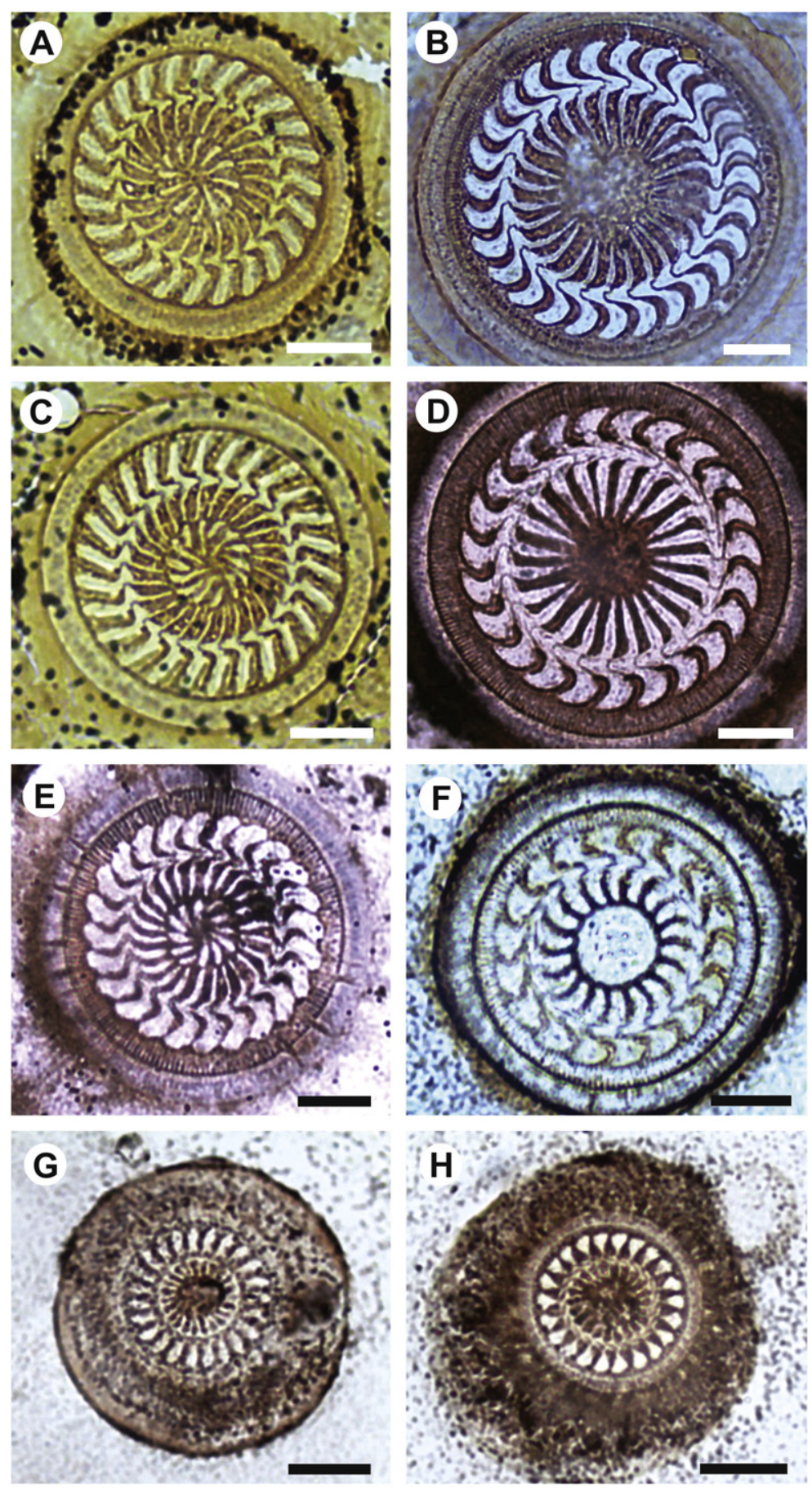

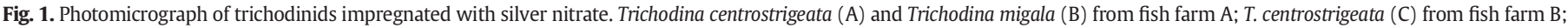
Trichodina heterodentata (D), T. centrostrigeata (E), Trichodina compacta (F), Tripartiella orthodens (G) and Paratrichodina africana (H) from fish farm C. Scale bars: $10 \mu \mathrm{m}$.

The anterior margin passed beyond the $y+1$ axis. The anterior and posterior margins were nearly straight and were parallel with each other. The posterior margin presented an L-shape. Blade apophysis was always present. The central portion exhibited a conic or triangular format and barely extended beyond the y axis. The rays extended considerably beyond the $\mathrm{y}+1$ axis.

T. migala (Fig. 1B) was of medium size. The blade was thin and did not contact the $y+1$ axis with its anterior margin. The anterior and posterior margins presented a similar curvature to each other. The central portion was long, extending nearly to the y axis. The ray apophysis was prominent and directed toward the anterior margin of the blade. The ray was thin, straight and parallel to the y axis.
The measurement data for both populations are shown in Table 1, and a schematic drawing is shown in Fig. 2A-B.

\subsection{Parasite identification: fish farm $B$}

In hatchery B, a low degree of parasitism was observed (31.8 \pm 19.07 trichodinids/fish). In this case, only $T$. centrostrigeata was found.

This T. centrostrigeata population (Fig. 1C) showed a similar morphology to that described in hatchery A. The measurement data for the evaluated taxonomic characters are shown in Table 4, and a schematic drawing is shown in Fig. 2C. 
Table 1

Measurements $(\mu \mathrm{m})$ for trichodinids found on Nile tilapia Oreochromis niloticus from hatchery A.

\begin{tabular}{|c|c|c|}
\hline Parasite species & Trichodina centrostrigeata & Trichodina migala \\
\hline Infection site & Body & Body \\
\hline Body $^{D}$ & $36.8 \pm 5.5(27.8-50.1 ; 41)$ & $64.1 \pm 5.7(51.0-78.0 ; 43)$ \\
\hline Adhesive disc ${ }^{\mathrm{D}}$ & $30.0 \pm 5.0(21.9-41.9 ; 41)$ & $54.0 \pm 5.3(43.2-67.8 ; 44)$ \\
\hline Border membrane $^{\mathrm{W}}$ & $3.5 \pm 0.6(2.1-5.4 ; 41)$ & $5.2 \pm 0.4(3.8-6.0 ; 44)$ \\
\hline Denticulate ring $^{\mathrm{D}}$ & $18.3 \pm 2.9(13.9-24.8 ; 43)$ & $34.2 \pm 3.4(26.8-43.4 ; 44)$ \\
\hline Centre ridges & $13.0 \pm 0.8(11-14 ; 24)$ & - \\
\hline Number of denticles & $26.3 \pm 1.3(23-29 ; 32)$ & $26.9 \pm 0.9(25-29 ; 43)$ \\
\hline Pines per denticle & $5.7 \pm 0.7(5-7 ; 23)$ & $8.5 \pm 1.2(10-14 ; 37)$ \\
\hline Denticle $^{\mathrm{L}}$ & $3.5 \pm 0.7(2.0-5.0 ; 43)$ & $8.0 \pm 0.8(5.7-9.7 ; 44)$ \\
\hline Blade $^{\mathrm{L}}$ & $4.2 \pm 0.8(2.9-5.7 ; 43)$ & $5.9 \pm 0.5(4.2-6.8 ; 44)$ \\
\hline Central portion $^{\mathrm{W}}$ & $1.5 \pm 0.3(1.0-2.2 ; 43)$ & $2.8 \pm 0.3(1.9-3.4 ; 44)$ \\
\hline Ray $^{\mathrm{L}}$ & $3.6 \pm 0.7(2.4-5.0 ; 43)$ & $7.4 \pm 1.0(4.8-9.4 ; 44)$ \\
\hline $\operatorname{Span}^{\mathrm{L}}$ & $9.3 \pm 1.5(6.9-12.2 ; 43)$ & $16.1 \pm 1.5(11.9-19.2 ; 44)$ \\
\hline
\end{tabular}

Measurement data were described as the mean \pm standard deviation (minimum-maximum; number of repetitions).

L Length.

D Diameter.

W Width.

\subsection{Parasite identification: fish farm $C$}

Intense parasitism $(1097.00 \pm 1080.60$ trichodinids/fish on the skin and $1132.60 \pm 949.71$ trichodinids/fish in the gills) was observed at hatchery $C$. Five populations of trichodinids were observed, including three species of the genus Trichodina, one species of the genus Tripartiella and another species of the genus Paratrichodina. Trichodina heterodentata Duncan, 1977, T. centrostrigeata, T. compacta, Tripartiella orthodens Basson and Van As, 1987 and P. africana (Fig. 1D-H) were described. Predominance of $T$. heterodentata on the skin and $P$. africana in the gills was noted.

Trichodina heterodentata was medium size. The blade exhibited a characteristic sickle shape that filled the space between the y axis and the $y+1$ axis. In some cases, the anterior margin passed beyond the $y+1$ axis. A prominent apophysis at the anterior margin of the blade was observed. The ray was long, straight and sharply pointed. The ray position varied from parallel to anteriorly directed toward the y axis.

The T. centrostrigeata specimens described at this hatchery exhibited a more curved blade than did the populations from other hatcheries. However, the morphological and morphometric characters were similar between all three studied populations.

T. compacta had a medium size. The blade was large, filling much of the area between the $y$ axis and the $y+1$ axis. The anterior margin of the blade generally extended beyond the $y+1$ axis and exhibited prominent apophysis. The ray was large and directed beyond the $y+1$ axis. The centre circle presented the same coloration of denticles and dark spots.

$T$. orthodens had a small size. The anterior margin of the blade was straight, whereas the posterior margin was curved and rounded. A well-developed posterior projection and a prominent anterior projection were characteristic of this species. The central portion was weakly developed. The ray was practically straight, with a homogeneous thickness of its tip, which was rounded and is arranged parallel to the y axis.

$P$. africana was small-sized, and its blade resembled an equilateral triangle with the top directed toward the centre of the body. The anterior margin did not touch the y axis, and prominent blade apophysis was present. The rays were straight and finger shaped, and they were usually arranged parallel to the y axis (toward the centre of the parasite).

Measurement data for the five populations are presented in two tables (Tables 2 and 3). Schematic drawings of the denticles are presented in Fig. 2D-H.
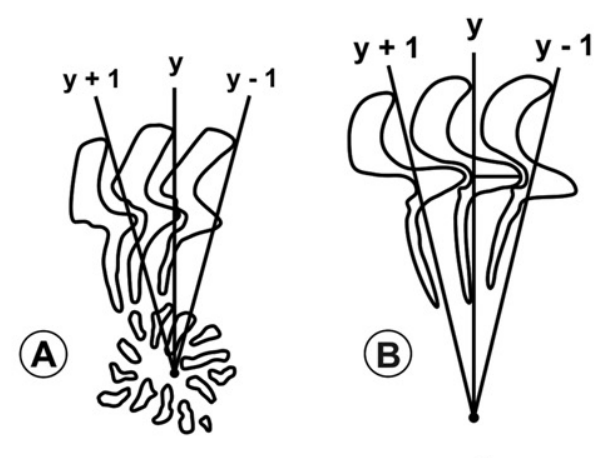

(C)
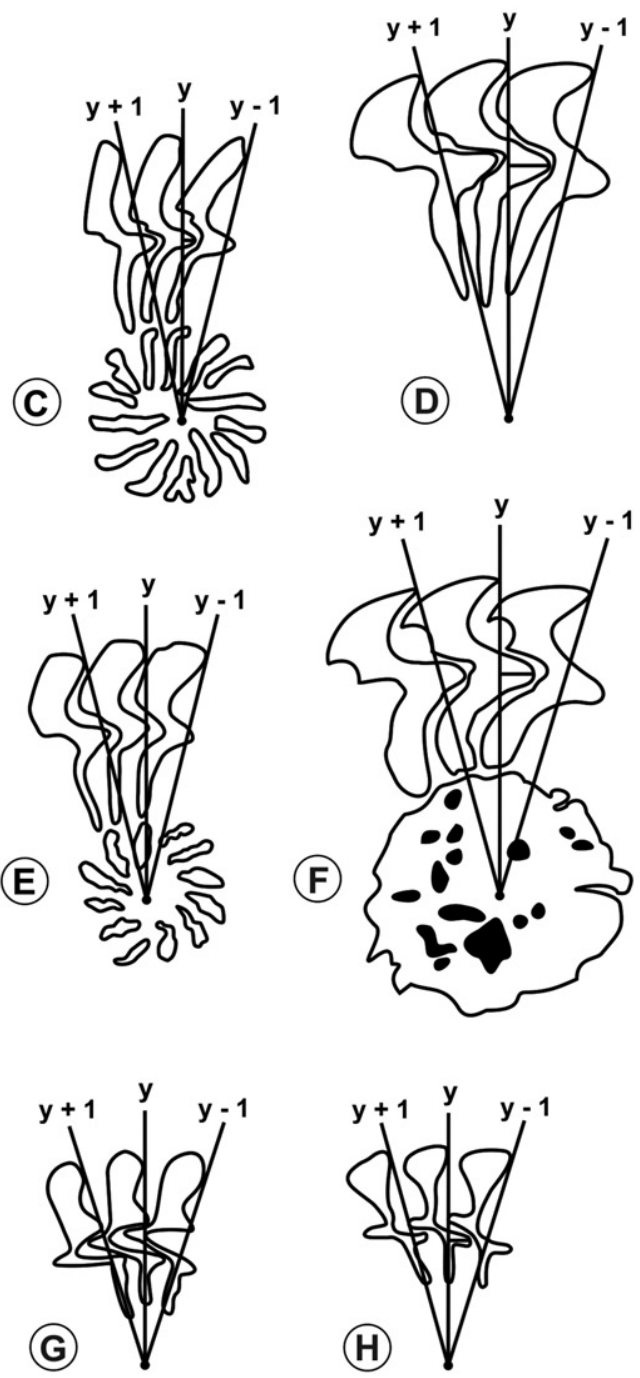

Fig. 2. Schematic drawing of the denticles of Trichodina centrostrigeata (A) and Trichodina migala (B) from fish farm A; T. centrostrigeata (C) from fish farm B; Trichodina heterodentata (D), T. centrostrigeata (E), Trichodina compacta (F), Tripartiella orthodens $(\mathrm{G})$ and Paratrichodina africana $(\mathrm{H})$ from fish farm C.

\subsection{Host-parasite interactions}

In the SEM analysis of larvae, skin lesions (suction areas and desquamation) were observed distributed across the body surface (Fig. 3A), with the highest concentration of these lesions occurring in the regions near the fins (Fig. 3B,C), and suction areas were also present on the eyes. The desquamation and suction areas exhibited variations in size and intensity, probably due to the presence of distinct populations of trichodinids ( $T$. centrostrigeata and $T$. migala: average body diameter $36.8 \mu \mathrm{m}$ and $64.1 \mu \mathrm{m}$, respectively). 
Table 2

Measurement $(\mu \mathrm{m})$ for trichodinids found on Nile tilapia Oreochromis niloticus from hatchery B.

\begin{tabular}{lc}
\hline Parasite species & \multicolumn{1}{l}{ Trichodina centrostrigeata } \\
\cline { 3 - 3 } Infection site & Body \\
\hline Body $^{\mathrm{D}}$ & $44.1 \pm 4.5(38.3-52.8 ; 17)$ \\
Adhesive disc $^{\mathrm{D}}$ & $36.1 \pm 3.9(31.2-44.1 ; 18)$ \\
Border membrane $^{\mathrm{W}}$ & $4.0 \pm 0.6(2.9-4.9 ; 18)$ \\
Denticulate ring $^{\mathrm{D}}$ & $22.0 \pm 2.6(18.6-27.2 ; 18)$ \\
Centre ridges $_{\text {Number of denticles }}$ & $12.9 \pm 1.1(10-14 ; 14)$ \\
Pines per denticle $_{\text {Denticle }}^{\mathrm{L}}$ & $26.6 \pm 1.5(23-29 ; 16)$ \\
Blade $^{\mathrm{L}}$ & $6.3 \pm 0.7(5-7 ; 9)$ \\
Central portion $^{\mathrm{W}}$ & $4.4 \pm 0.6(3.3-5.9 ; 18)$ \\
Ray $^{\mathrm{L}}$ & $5.3 \pm 0.6(3.8-6.3 ; 18)$ \\
Span $^{\mathrm{L}}$ & $1.9 \pm 0.3(1.6-2.7 ; 18)$ \\
\hline
\end{tabular}

Measurement data were described as the mean \pm standard deviation (minimummaximum; number of repetitions)

L Length.

D Diameter.

W Width.

Parasitism was almost 10 times greater in juveniles than in larvae. However, no suction areas were observed spread across the body surface, which exhibited intact and well-developed scales. In rare instances, suction areas were found in regions devoid of scales, such as the head. These results suggest that parasitism by trichodinids scarcely affects the outer surface of juvenile hosts, in contrast to the larval stage.

\subsection{Treatment}

The currently used treatment protocol $\left(1 \mathrm{mLL}^{-1}\right.$ formaldehyde $+1 \%$ $1 \%$ sodium chloride) and the protocol using half the amount of the disinfectant $\left(0.5 \mathrm{~mL} \mathrm{~L}^{-1}\right.$ formaldehyde $+1 \%$ sodium chloride) showed similar results $(p>0.05)$, exhibiting almost $100 \%$ effectiveness in the treatment of trichodiniasis (Fig. 4). The protocol using one-quarter the amount of formaldehyde $\left(0.25 \mathrm{~mL} \mathrm{~L}^{-1}\right.$ formaldehyde $+1 \%$ sodium chloride) was also effective in controlling trichodiniasis; however, its effectiveness was statistically lower $(\mathrm{p}<0.05)$ compared with other treatments (Fig. 4). There was no mortality or behavioural changes in the animals during treatment.

\section{Discussion}

New reports of uncommon trichodinids in South America have increased. Recently, Valladão et al. (2015b) have described parasitism by
Table 4

Measurements $(\mu \mathrm{m})$ for trichodinids of the genera Tripartiella and Paratrichodina found on Nile tilapia Oreochromis niloticus from hatchery C.

\begin{tabular}{|c|c|c|}
\hline Parasite species & Tripartiella orthodens & Paratrichodina africana \\
\hline Infection site & Gills & Gills \\
\hline Body $^{\mathrm{D}}$ & $23.6 \pm 1.7(20.6-27.8 ; 18)$ & $22.0 \pm 2.2(18.0-26.8 ; 44)$ \\
\hline Adhesive disc ${ }^{\mathrm{D}}$ & $19.5 \pm 1.5(16.9-22.7 ; 18)$ & $18.3 \pm 2.0(14.4-22.8 ; 44)$ \\
\hline Border membrane $^{\mathrm{W}}$ & $2.1 \pm 0.3(1.6-2.7 ; 18)$ & $1.9 \pm 0.2(1.4-2.7 ; 44)$ \\
\hline Denticulate ring ${ }^{\mathrm{D}}$ & $10.2 \pm 1.1(9.0-12.6 ; 18)$ & $10.6 \pm 1.3(8.0-14.5 ; 44)$ \\
\hline Number of denticles & $21.5 \pm 1.8(19-26 ; 18)$ & $22.1 \pm 1.7(20-27 ; 43)$ \\
\hline Pines per denticle & - & - \\
\hline Denticle $^{\mathrm{L}}$ & $2.5 \pm 0.3(2.1-3.1 ; 17)$ & $2.2 \pm 0.3(1.2-2.9 ; 44)$ \\
\hline Blade $^{\mathrm{L}}$ & $3.3 \pm 0.4(2.2-3.9 ; 18)$ & $2.5 \pm 0.3(1.9-3.2 ; 44)$ \\
\hline Central portion ${ }^{\mathrm{W}}$ & $1.2 \pm 0.1(0.9-1.4 ; 18)$ & $1.1 \pm 0.2(0.7-1.4 ; 44)$ \\
\hline Ray $^{\mathrm{L}}$ & $1.8 \pm 0.3(1.5-2.3 ; 18)$ & $1.6 \pm 0.3(0.9-2.6 ; 44)$ \\
\hline $\operatorname{Span}^{\mathrm{L}}$ & $6.3 \pm 0.6(5.1-7.2 ; 18)$ & $5.2 \pm 0.5(4.3-6.9 ; 44)$ \\
\hline
\end{tabular}

Measurement data were described as the mean \pm standard deviation (minimum-maximum; number of repetitions).

$\mathrm{L}$ Length.

D Diameter.

W Width.

the Euro-Asiatic trichodinid Trichodina modesta Lom, 1970 in cultivated Betta splendens Regan, 1910 in Brazil. Several years ago, Van As and Basson (1989) described the risks of introducing trichodinids into new areas through the dispersal of cichlids worldwide. The trichodinid species identified in this study ( $T$. centrostrigeata, $T$. compacta, $T$. heterodentata, $T$. migala, $T$. orthodens, $P$. africana) have mainly been observed as parasites of cichlids in African and Asian countries (Duncan, 1977; Basson et al., 1983; Kazubski and El-Tantawy, 1986; Van As and Basson, 1989; Van As and Basson, 1992). In Brazil, only T. centrostrigeata (Bittencourt et al., 2014), T. compacta (Ghiraldelli et al., 2006; Jerônimo et al., 2011; Zago et al., 2014), T. magna (Martins and Ghiraldelli, 2008; Zago et al., 2014), Trichodina nobilis Chen, 1963 (Bittencourt et al., 2014) and P. africana (Pantoja et al., 2012; Tavares-Dias et al., 2013; Valladão et al., 2013; Bittencourt et al., 2014) had previously been described as affecting Nile tilapia.

Through morphometric and morphological comparisons with the original description of T. migala performed by Van As and Basson (1989), it was possible to conduct the first identification of this species in South America. Additionally, this study provides the first identification of T. orthodens in South America. T. orthodens is characterised as an exclusive gill parasite and was first described parasitizing Tilapia rendali Boulenger, 1896 in South Africa (Basson and Van As, 1987). Recently, Zhao and Liu (2013) have reported the occurrence of this species on Pelteobagrus nitidus Sauvage \& Dabry de Thiersant, 1874 in China.

Table 3

Measurements $(\mu \mathrm{m})$ for trichodinids on Nile tilapia Oreochromis niloticus from hatchery C.

\begin{tabular}{|c|c|c|c|}
\hline Parasite species & Trichodina heterodentata & Trichodina centrostrigeata & Trichodina compacta \\
\hline Infection site & Body & Body and Gills & Body \\
\hline Body $^{\mathrm{D}}$ & $50.5 \pm 4.1(38.4-59.2 ; 110)$ & $43.3 \pm 4.9(36.2-55.5 ; 30)$ & $49.6 \pm 6.5(36.3-60.7 ; 35)$ \\
\hline Adhesive disc ${ }^{\mathrm{D}}$ & $42.3 \pm 4.0(31.3-50.3 ; 114)$ & $36.0 \pm 4.7(29.0-47.3 ; 31)$ & $40.8 \pm 6.0(28.4-51.0 ; 35)$ \\
\hline Border membrane $^{\mathrm{W}}$ & $4.2 \pm 0.4(3.2-5.2 ; 112)$ & $3.9 \pm 0.4(2.2-4.6 ; 31)$ & $4.5 \pm 0.5(3.4-5.2 ; 36)$ \\
\hline Denticulate ring ${ }^{\mathrm{D}}$ & $25.4 \pm 3.1(12.2-32.4 ; 114)$ & $22.0 \pm 2.5(18.1-26.9 ; 31)$ & $25.2 \pm 4.5(16.0-32.4 ; 37)$ \\
\hline Centre ridges & - & $12.4 \pm 1.4(9-15 ; 30)$ & - \\
\hline Central circle $^{\mathrm{D}}$ & - & - & $13.0 \pm 3.3(6.3-19.1 ; 36)$ \\
\hline Number of denticles & $23.7 \pm 2.2(11-27 ; 113)$ & $25.9 \pm 2.1(21-29 ; 32)$ & $19.4 \pm 1.5(17-22 ; 36)$ \\
\hline Pines per denticle & $11.3 \pm 1.9(7-16 ; 114)$ & $9.1 \pm 1.1(7-11 ; 17)$ & $9.2 \pm 1.3(6-11 ; 32)$ \\
\hline Denticle $^{\mathrm{L}}$ & $6.9 \pm 0.6(5.6-9.7 ; 114)$ & $4.5 \pm 0.6(3.5-6.0 ; 31)$ & $8.0 \pm 1.1(4.4-10.3 ; 36)$ \\
\hline Blade $^{\mathrm{L}}$ & $4.2 \pm 0.4(2.9-5.2 ; 114)$ & $4.9 \pm 0.7(3.9-6.3 ; 31)$ & $4.0 \pm 0.5(3.1-4.8 ; 36)$ \\
\hline Central portion $^{\mathrm{W}}$ & $2.3 \pm 0.4(1.4-3.2 ; 114)$ & $2.1 \pm 0.2(1.5-2.7 ; 31)$ & $3.0 \pm 0.4(2.3-4.0 ; 37)$ \\
\hline Ray $^{\mathrm{L}}$ & $6.1 \pm 1.0(3.1-8.1 ; 114)$ & $4.4 \pm 0.9(2.7-7.3 ; 31)$ & $4.1 \pm 0.4(3.4-5.0 ; 37)$ \\
\hline $\operatorname{Span}^{\mathrm{L}}$ & $12.5 \pm 1.4(7.8-15.5 ; 114)$ & $11.4 \pm 1.5(8.6-15.1 ; 31)$ & $11.1 \pm 0.9(9.1-12.8 ; 36)$ \\
\hline
\end{tabular}

Measurement data were described as the mean \pm standard deviation (minimum-maximum; number of repetitions).

L Length.

D Diameter.

w width. 

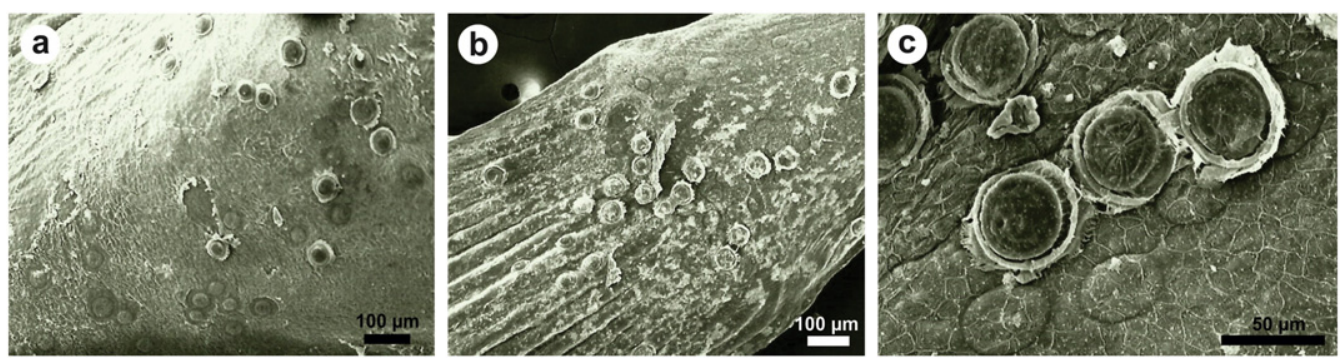

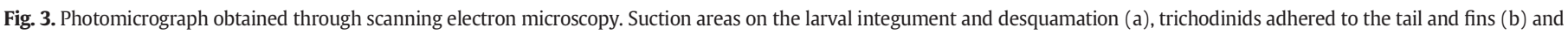
suction areas associated with trichodinids across the body surface of the larvae (c).

The morphological and morphometric characteristics of the population identified in Brazil agree with the original description and the data obtained by Zhao and Liu (2013).

Concordantly with the present study, Valladão et al. (2014) have described larvae of Prochilodus lineatus Valenciennes, 1836, a South American fish that were severely affected by trichodiniasis but data on the effect of parasitism according to other host life stages are scarce. Both studies have revealed that hatcheries can be highly affected. This parasitism directly affects the larvae because their main defence mechanisms are not fully developed, such as their scales, which appear to be a major barrier to this type of parasitosis. In addition, the parasitism observed in the eyes and on sensitive ciliary structures of the larvae affects their ability to capture live food in earthen ponds and to escape from predators such as birds and odonata larvae, which are threats that are commonly found in aquaculture (Dias-Neto et al., 2015). Despite the greater intensity of infestation, the juveniles, which have more developed scales and tougher skin, showed a lower intensity of suction areas and lesions over their bodies. These changes were observed at a low frequency and were always associated with regions either without scales or with few scales, in contrast to the situation observed in the larvae, which were affected over all of their skin. As previously mentioned, Nile tilapia reproduction commonly occurs naturally in earthen ponds, and the larvae are exposed to pathogens present in the breeding tanks. A productive strategy (for tilapia) that can prevent severe parasitism in early stages is the collection of eggs from the mouths of the females, followed by indoor incubation and intensive hatching in the laboratory. Then, well-developed juveniles could be released into earthen tanks for growth.

The three treatments applied in the present study did not cause larval mortality, and the protocol involving half the amount of formaldehyde commonly used in the field was similarly effective in treating

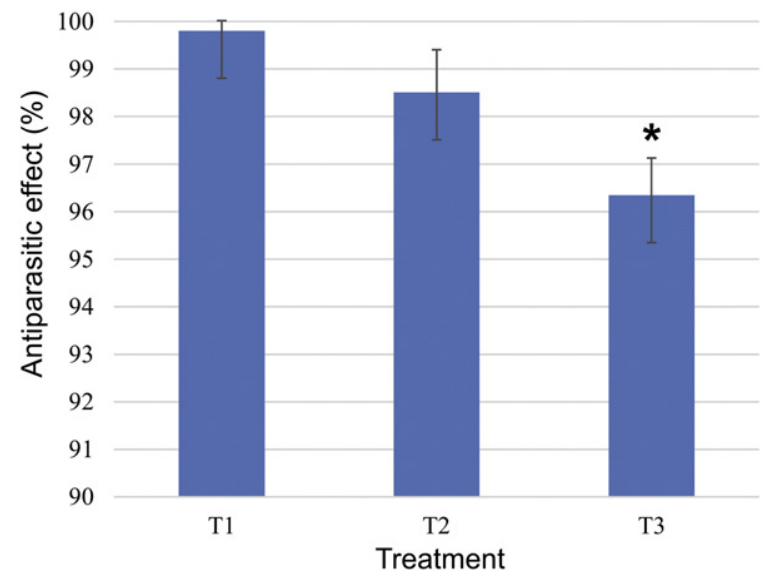

Fig. 4. Antiparasitic effect of bath treatments (once during $15 \mathrm{~min}$ ) against trichodinids. TR $1=1 \mathrm{~mL} \mathrm{~L}^{-1}$ formaldehyde $+1 \%$ sodium chloride; TR $2=$ half the amount of the disinfectant $\left(0.5 \mathrm{~mL} \mathrm{~L}^{-1}\right.$ formaldehyde $+1 \%$ sodium chloride); TR $3=$ one-quarter the amount of formaldehyde $\left(0.25 \mathrm{~mL} \mathrm{~L}^{-1}\right.$ formaldehyde $+1 \%$ sodium chloride) trichodiniasis. Despite the possibility of reducing the use of formaldehyde, the addition of this and other disinfectants to water is viewed critically. Therefore, it is highly encouraged to use ecologically friendly substances for the treatment of parasitic diseases of fish. The use of natural products such as herbal medicines can also be an effective option for the treatment of fish diseases, including trichodiniasis (Valladão et al., 2015a).

Trichodiniasis presents greater pathogenicity in fish in the larval stage than in juveniles, which already exhibit a similar phenotype to that of adult fish. Therefore, the adoption of preventive measures and indoor production strategies during the first days of larval life is highly recommended. Treatment with formaldehyde at a concentration of $0.5 \mathrm{~mL} \mathrm{~L}^{-1}+1 \%$ sodium chloride proved to be as effective as the concentration that is commonly used in the field, making the use of higher dosages for the treatment of trichodiniasis unjustified.

\section{Conflict of interest}

The authors declare no conflicts of interest.

\section{Acknowledgements}

The authors thank PreVet Aquatic Health for support in the field sampling and all of the fish farms for providing fish in this study. We thank Claudia Aparecida Rodrigues for performing the SEM procedure, and we thank FAPESP for a scholarship (grant number: 2013/20067-2).

\section{References}

Abdel-Baki, A.S., Sakran, T., Fayed, H., Zayed, E., 2011. Trichodina fahaka (Ciliophora: Peritrichia) in Tetraodon fahaka from Nile River, Egypt: seasonality and histopathology. Sci. Res. Essays 6, 1583-1587.

Arthur, J.R., Lom, J., 1984. Trichodinid protozoa (Ciliophora: Peritrichida) from freshwater fishes of Rybinsk Reservoir, USSR1. J. Eukaryot. Microbiol. 31, 82-91.

Basson, L., Van As, J.G., 1987. Trichodinid (Ciliophora; Peritricha) gill parasites of freshwater fish in South Africa. Syst. Parasitol. 9, 143-151.

Basson, L., Van As, J.G., Paperna, I., 1983. Trichodinid ectoparasites of cichlid and cyprinid fishes in South Africa and Israel. Syst. Parasitol. 5 (4), 245-257.

Bittencourt, L.S., Pinheiro, D.A., Cárdenas, M.Q., Fernandes, B.M., Tavares-Dias, M., 2014. Parasites of native Cichlidae populations and invasive Oreochromis niloticus (Linnaeus, 1758) in tributary of Amazonas River (Brazil). Rev. Bras. Parasitol. Vet. 23 (1), 44-54.

Dias-Neto, J., Valladão, G.M.R., Viadanna, P.H.O., Pilarski, F., 2015. Three strategic feeds during hatchering of Nile tilapia: effects on organs integrity, parasitism and performance parameters (Under publication process).

Duncan, B.L., 1977. Urceolariid ciliates, including three new species, from cultured Philippine fishes. Trans. Am. Microsc. Soc. 96, 76-81.

Ekanem. D.A., Oblekezie, A.I., 1996. Growth reduction in African catfish fry infected with Trichodina maritinkae Basson \& Van as, 1991 (Ciliophora: Peritrichida). J. Aquacult. Trop. 11, 91-96.

Ghiraldelli, L., Martins, M.L., Adamante, W.B., Yamashita, M., 2006. First record of Trichodina compacta Van As \& Basson, 1989 (Protozoa: Ciliophora) from cultured Nile tilapia in the State of Santa Catarina, Brazil. Int. J. Zool. Res. 2, 369-375.

Jerônimo, G.T., Speck, G.M., Cechinel, M.M., Gonçalves, E.L., Martins, M.L., 2011. Seasonal variation on the ectoparasitic communities of Nile tilapia cultured in three regions in southern Brazil. Braz. J. Biol. 71 (2), 365-373.

Kazubski, S.L., El-Tantawy, S.A.M., 1986. The ciliate Paratrichodina africana sp. n. (Peritricha, Trichodinidae) from Tilapia fish (Cichlidae) from Africa. Acta Protozool. 25, 433-438 
Klein, B.M., 1958. The dry silver method and its proper use. J. Protozool. 5, 99-103.

Lom, J., 1958. A contribution to the systematics and morphology of endoparasitic trichodinids from amphibians, with a proposal of uniform specific characteristics. J. Protozool. 5, 251-263.

Martins, M.L., Ghiraldelli, L., 2008. Trichodina magna Van As \& Basson, 1989 (Ciliophora: Peritrichia) from cultured Nile tilapia in the State of Santa Catarina, Brazil. Braz. J. Biol. 68, 169-172.

Martins, M.L., Shoemaker, C.A., Xu, D., Klesius, P.H., 2011. Effect of parasitism on vaccine efficacy against Streptococcus iniae in Nile tilapia. Aquaculture 314, 18-23.

Mitra, A.K., Bandyopadhyay, P.K., Gong, Y., 2013. Studies on Trichodinid and Chilodonellid Ciliophorans (Protozoa: Ciliophora) in the Indian freshwater and estuarine fishes with description of Trichodinella sunderbanensis sp. nov. and Trichodina nandusi sp. nov. Parasitol. Res. 112 (3), 1077-1085.

Pantoja, W.M.F., Neves, L.R., Dias, M.K.R., Marinho, R.G.B., Montagner, D., Tavares-Dias, M. 2012. Protozoan and metazoan parasites of Nile tilapia Oreochromis niloticus cultured in Brazil. Rev. MVZ Córdoba 17, 2812-2819.

Shao, Z.J., 2001. Aquaculture pharmaceuticals and biologicals: current perspectives and future possibilities. Adv. Drug Deliv. Rev. 50 (3), 229-243.

Tavares-Dias, M., Marchiori, N.D.C., Martins, M.L., 2013. Paratrichodina africana (Ciliophora: Trichodinidae) of wild and cultured Nile tilapia in the Northern Brazil. Rev. Bras. Parasitol. Vet. 22 (2), 248-252.

Valladão, G.M.R., Gallani, S.U., Pilarski, F., 2015a. Phytotherapy as an alternative for treating fish disease. J. Vet. Pharmacol. Ther. 38 (5), 417-428.

Valladão, G.M.R., Giannecchini, L.G., Martins, M.L., Pádua, S.B., 2015b. Trichodina modesta; an exotic ciliate in the neotropical area parasitizing an unusual host. Rev. Bras. Parasitol. Vet. 24 (2), 162-167.
Valladão, G.M.R., Gallani, S.U., Pádua, S.B., Martins, M.L., Pilarski, F., 2014. Trichodna heterodentata (Ciliophora) infestation on Prochilodus lineatus larvae: a host-parasite relationship study. Parasitology 141, 662-669.

Valladão, G.M.R., Pádua, S.B., Gallani, S.U., Menezes-Filho, R.N., Dias-Neto, J., Martins, M.L, Pilarski, F., 2013. Paratrichodina africana (Ciliophora): a pathogenic gill parasite in farmed Nile tilapia. Vet. Parasitol. 197, 705-710.

Van As, J.G., Basson, L., 1992. Trichodinid ectoparasites (Ciliophora: Peritrichida) of freshwater fishes of the Zambesi River System, with a reappraisal of host specificity. Syst Parasitol. 22, 81-109.

Van As, J.G., Basson, L., 1989. A further contribution to the taxonomy of the Trichodinidae (Ciliophora: Peritrichia) and a review of the taxonomic status of some fish ectoparasitic trichodinids. Syst. Parasitol. 14 (3), 157-179.

Yemmen, C., Ktari, M.H., Bahri, S., 2011a. Seasonality and histopathology of Trichodina puytoraci Lom, 1962, a parasite of flathead mullet (Mugil cephalus) from Tunisia. Acta Adriat. 52, 15-20.

Yemmen, C., Quilichini, Y., Ktari, M.H., Marchand, B., Bahri, S., 2011b. Morphological, ecological and histopathological studies of Trichodina gobii Raabe, 1959 (Ciliophora: Peritrichida) infecting the gills of Solea aegyptiaca. Protistology 6 (4), 258-263.

Zago, A.C., Franceschini, L., Garcia, F., Schalch, S.H.C., Gozi, K.S., Silva, R.J., 2014. Ectoparasites of Nile tilapia (Oreochromis niloticus) in cage farming in a hydroelectric reservoir in Brazil. Rev. Bras. Parasitol. Vet. 23 (2), 171-178.

Zhao, F.T.Y., Liu, C., 2013. First records of three Tripartiella species (Ciliophora, Oligohymenophora, Peritrichida) from freshwater fishes along Yangtze River in China. Zootaxa 3681 (2), 169-174. 